\title{
JNPH
}

Volume 5 No. 1 (Juli 2017)

(C) The Author(s) 2017

\section{IDENTIFIKASI BORAKS PADA ROTI DI KOTA BENGKULU TAHUN 2017}

\author{
IDENTIFICATION OF BORAKS IN BREAD IN BENGKULU CITY 2017
}

\author{
JON FARIZAL, PUTRI WIDELIA WELKRIANA \\ POLTEKKES KEMENKES BENGKULU
}

\begin{abstract}
ABSTRAK
Latar Belakang Mulai banyak orang mempunyai usaha membuat roti dan membuka toko roti di Kota Bengkulu. Saat ini, masih banyak ditemukan pemakaian bahan pengawet yang dilarang untuk digunakan dalam pangan dan berbahaya bagi kesehatan, seperti boraks. Boraks di dalam makanan mempunyai sifat bisa mengembangkan, membunuh mikroba, serta memberi efek kenyal. Meski begitu, boraks tidak dibolehkan untuk dikonsumsi karena bisa beracun bagi tubuh. Sementara itu, orang yang mengonsumsi boraks dalam jangka waktu yang lama dapat memicu timbulnya kanker, terlebih kanker pada otak, hati, dan gangguan fungsi ginjal. Penelitian ini bertujuan untuk mengetahui distribusi frekuensi ada atau tidaknya boraks pada roti di Kota Bengkulu Tahun 2017. Metode Penelitian ini menggunakan penelitian survei deskriptif dengan pendekatan laboratorium. Jumlah responden penelitian ini sebanyak 20 sampel roti. Pemeriksaan laboratorium secara kualitatif dengan metode tes kit. Hasil diketahui seluruh sampel (100\%) identifikasi boraks pada roti di Kota Bengkulu negatif karena produsen roti menggunakan bahan pengawet yang dilarang selain boraks. Kesimpulan dari penelitian ini yaitu dari seluruh sampel roti negatif mengandung boraks dan tidak satupun sampel roti positif mengandung boraks. Perlu dilakukan penelitian lebih lanjut mengenai penggunaan bahan kimia berbahaya yang lain di dalam roti selain boraks.
\end{abstract}

Kata kunci : roti, boraks, bahan pengawet

\begin{abstract}
Background: Many people started making bread and bakeries in Bengkulu City. Currently, there is still a lot of use of preservatives that are prohibited for use in food and harmful to health, such as borax. Borax in the food has properties that can develop, kill microbes, and give a chewy effect. Even so, borax is not allowed to be consumed because it can be toxic to the body. Meanwhile, people who take borax for long periods of time can lead to cancer, especially cancer of the brain, liver, and impaired kidney function. This study aims to determine the frequency distribution of whether there is or not borax on bread in the city of Bengkulu in 2017. This research method used descriptive survey with laboratory approach. The number of respondents of this study were 20 samples of bread. The examination of laboratory on qualitative with test kit method. The result is known that all samples $(100 \%)$ of borax identification on bread in Bengkulu City are negative because the bread producers use preserved substances other than borax. The conclusion of this study is that of all samples of negative bread containing borax and none of the positive bread samples contain borax. Further research is needed on the use of other harmful chemicals in bread other than borax.
\end{abstract}

Keywords: bread, borax, preservatives 


\section{PENDAHULUAN}

Penggunaan bahan tambahan pangan (food additives) pada masyarakat semakin meningkat seiring dengan berkembangnya industri pengolahan makanan di Indonesia. Penyalahgunaan bahan-bahan kimia dalam makanan merupakan tindakan yang melanggar aturan dan membahayakan konsumen. Bahan tambahan yang diizinkan pun apabila digunakan dalam dosis tinggi juga berbahaya bagi kesehatan (Alsuhendra dan Ridawati, 2013).

Salah satu contoh pangan yang cukup banyak dikonsumsi masyarakat di Indonesia sekarang sebagai makanan jajanan adalah roti. Pangan ini merupakan makanan yang sudah dikenal sejak dulu. Jenis makanan ini biasa dikonsumsi oleh masyarakat dari berbagai belahan dunia. Roti digemari karena rasanya yang lezat disamping nilai gizinya yang baik. Banyak jenis roti yang beredar di pasaran, salah satunya adalah roti tawar yang sering digunakan sebagai menu sarapan pagi sebagian masyarakat Indonesia (Mizana, Suharti dan Amir, 2016).

Mulai banyak orang mempunyai usaha membuat roti dan membuka toko roti di Kota Bengkulu. Hal ini disebabkan karena peminat roti semakin bertambah setiap harinya. Biasanya roti dibeli untuk acara-acara seminar, arisan, menyambut hari raya, dan konsumsi sehari-hari. Inilah yang menjadi alasan mengapa usaha roti diminati oleh banyak orang (Gabrienda, Nusril dan Badrudin, 2012). Terjadinya penyalahgunaan boraks dalam pengolahan roti meskipun produsen/pengusaha mengetahui bahaya menggunakan pengawet boraks, tetap saja digunakan karena hal ini biasanya dilatarbelakangi oleh faktor pendidikan, ekonomi, dan mudahnya mendapatkan pengawet boraks. Walaupun dilarang penggunaan boraks dalam makanan, boraks dalam roti terus dikonsumsi, hal ini disebabkan karena konsumen tidak mengetahui apakah dalam olahan roti tersebut terdapat zat pengawet boraks yang merupakan bahan yang dilarang digunakan dalam makanan. Oleh karena itu, perlu adanya pengawasan oleh pihak terkait mengenai penggunaan bahan tambahan pangan agar makanan yang dikonsumsi baik untuk kesehatan (Abas, 2014).

Boraks di dalam makanan mempunyai sifat bisa mengembangkan, membunuh mikroba, serta memberi efek kenyal. Boraks sering disalah gunakan oleh produsen untuk dijadikan bahan tambahan makanan (BTM) pada tahu, bakso, bihun, mie, kerupuk, maupun lontong (Padmaningrum dan Marwati, 2013). Boraks juga dimanfaatkan sebagai obat-obatan, seperti salep, obat kumur, dan semprot hidung. Meski begitu, boraks tidak dibolehkan untuk dikonsumsi karena bisa beracun bagi tubuh. Orang yang keracunan boraks umumnya mengalami gejala muntah-muntah, diare, dan pusing. Sementara itu, orang yang mengonsumsi boraks dalam jangka waktu yang lama dapat memicu timbulnya kanker, terlebih kanker pada otak, hati, dan gangguan fungsi ginjal. Boraks yang terdapat dalam makanan akan diserap oleh tubuh dan disimpan secara kumulatif dalam otak, hati, atau testis (buah zakar), sehingga dosis boraks dalam tubuh menjadi tinggi (Helmawati, 2015).

Berbagai penelitian sudah dilakukan terkait penggunaan boraks pada makanan. Berdasarkan hasil penelitian uji sampel terhadap 17 pedagang bakso tusuk yang berjualan di lingkungan Sekolah Dasar di Kecamatan Bangkinang bahwa hampir seluruh pedagang menggunakan boraks pada produk bakso tusuk (Nurkholidah, Ilza dan Jose, 2012). Berdasarkan pemeriksaan boraks yang dilakukan pada $13 \mathrm{mi}$ basah mentah, 4 diantaranya $30 \%$ nya mengandung boraks dan tidak ada yang mengandung formalin. Dari 7 mi basah matang yang diperiksa kandungan boraksnya, seluruhnya mengandung boraks dan formalin (100\%) (Habsah, 2012). Sedangkan pada penelitian ini, roti yang digunakan sebagai sampel di Kota Bengkulu Tahun 2017. Berdasarkan uraian tersebut maka peneliti tertarik melakukan penelitian tentang "Identifikasi Boraks pada Roti di Kota Bengkulu Tahun 2017". 


\section{METODE PENELITIAN}

Penelitian ini menggunakan jenis penelitian analisis survei deskriptif laboratorium yang dilakukan untuk mengetahui gambaran atau fenomena yang terjadi di dalam suatu populasi tertentu (Notoatmodjo, 2010), mengetahui ada atau tidaknya boraks pada roti di Kota Bengkulu Tahun 2017 yang dilakukan dengan pemeriksaan di laboratorium secara kualitatif. Penelitian ini menggunakan variabel tunggal yaitu identifikasi boraks pada roti di Kota Bengkulu Tahun 2017. Penelitian dilakukan melalui metode kualitatif. Populasi dalam penelitian ini adalah roti tawar dan roti manis yang dijual di Kota Bengkulu Tahun 2017.

Sampel dalam penelitian ini diambil dari semua jumlah populasi roti manis yang diperdagangkan di wilayah Kota Bengkulu Tahun 2017, dengan menggunakan metode Total Sampling dan sebanyak 20 sampel roti manis.

Penelitian ini dilakukan di Poltekkes Kemenkes Bengkulu, tempat pemeriksaan di Laboratorium Terpadu Poltekkes Kemenkes Bengkulu. Waktu penelitian dimulai dari bulan Desember 2016 sampai Mei 2017.

\section{HASIL PENELITIAN}

Analisa univariat digunakan untuk melihat distribusi frekuensi identifikasi Boraks pada Roti di Kota Bengkulu Tahun 2017. Hasilnya dapat dilihat pada tabel berikut :

Tabel 1 Distribusi Frekuensi Identifikasi Boraks Pada Roti Manis di Kota Bengkulu Tahun 2017.

\begin{tabular}{ccc}
\hline $\begin{array}{c}\text { Hasil } \\
\text { Pemeriksaan }\end{array}$ & Frekuensi & Persentase \\
\hline Boraks Positif & 0 & $0 \%$ \\
Boraks Negatif & 20 & $100 \%$ \\
\hline Total & 20 & $100 \%$ \\
\hline
\end{tabular}

Tabel 1 diketahui seluruh sampel (100 \%) identifikasi boraks pada roti di Kota
Bengkulu negatif.

\section{PEMBAHASAN}

Berdasarkan hasil penelitian yang telah dilakukan bahwa dari 20 sampel roti, didapatkan hasil $0 \%$ positif boraks sedangkan $100 \%$ negatif boraks, yang berarti memenuhi persyaratan kesehatan menurut Peraturan Menteri Kesehatan Republik Indonesia Nomor 033 Tahun 2012 tentang bahan tambahan pangan. Hal ini bisa dinyatakan bahwa bebas dari boraks. Namun hasil ini bukan menjamin boraks tidak terdapat pada makanan lain pada waktu yang akan datang, sehingga perlu dilakukan analisis yang berkelanjutan, seperti identifikasi asam salisilat dan garamnya, dietilpirokarbonat, dulsin, formalin, kalium bromat, kalium klorat, kloramfenikol, minyak nabati yang dibrominasi, nitrofurazon, dulkamara, kokain, nitrobenzen, sinamil antranilat, dihidrosafrol, biji tonka, minyak kalamus, minyak tansi dan minyak sasafras. Roti memiliki masa kadaluwarsa yang berbeda karena disebabkan oleh tingkat dan cara pengolahan roti itu sendiri, roti yang baik bisa bertahan 1-6 hari tergantung suhu dan lama penyimpanan. Apabila roti bisa bertahan melebihi 7 hari maka roti tersebut diduga mengandung zat pengawet berbahaya seperti boraks. Roti adalah jenis olahan makanan yang sifatnya cepat berjamur dan mudah rusak, hal ini bisa dipengaruhi oleh suhu dan lama masa penyimpanan. Ciri-ciri roti yang mengandung boraks adalah bisa bertahan sampai $>15$ hari dan belum mengalami perubahan fisik, baunya apek dan belum ditumbuhi jamur, strukturnya apabila dipilin akan rontok (Abas, 2014).

\section{KESIMPULAN}

Berdasarkan hasil penelitian dan pembahasan mengenai identifikasi boraks pada roti di kota Bengkulu Tahun 2017 dapat disimpulkan bahwa dari seluruh sampel roti, negatif mengandung boraks dan tidak satupun sampel roti positif mengandung boraks. 


\section{SARAN}

1. Bagi Masyarakat

Masyarakat harus tahu bahaya serta dampak kesehatan yang ditimbulkan dan berhati-hati dalam memilih merek roti dan mengonsumsi roti di Kota Bengkulu.

\section{Bagi Instansi Terkait}

Instansi terkait lebih memperhatikan penggunaan bahan kimia pada jajanan yang tersebar di masyarakat dan dilakukan pemeriksaan secara berkala tentang penggunaan boraks pada roti di Kota Bengkulu.

\section{Bagi Peneliti Lain}

Perlu dilakukan penelitian lebih lanjut mengenai penggunaan bahan kimia berbahaya yang lain di dalam roti selain boraks.

\section{Bagi Intitusi}

Dapat menambah referensi karya tulis ilmiah tentang boraks sebagai bahan pengawet pada roti.

\section{DAFTAR PUSTAKA}

Abas, S. W. (2014) Uji Kandungan Boraks pada Roti yang dijual di Kawasan Pasar Sentral Kota Gorontalo. Universitas Negeri Gorontalo.

Alsuhendra dan Ridawati (2013) Bahan Toksik dalam Makanan. Pertama. Edited by P. Latifah. Bandung: PT. Remaja Rosdakarya.

Gabrienda, G., Nusril and Badrudin, R. (2012) 'Pemasaran Pengusaha Roti Di Kota Bengkulu Analysis Of Market Orientation And Marketing Mix Strategies Of Bakery Entrepreneurs In Bengkulu', Agrisep, 11(2), pp. 153-163.

Habsah (2012) Gambaran Pengetahuan Pedagang Mi Basah terhadap Perilaku Penambahan Boraks dan Formalin pada
Mi Basah di Kantin-kantin Universitas X Depok Tahun 2012. Universitas Indonesia.

Helmawati, T. (2015) Lezat Sih Tapi Sehat Nggak Ya? Edited by Vebru. Yogyakarta: Notebook.

Mizana, D. K., Suharti, N. and Amir, A. (2016) 'Artikel Penelitian Identifikasi Pertumbuhan Jamur Aspergillus Sp pada Roti Tawar yang Dijual di Kota Padang Berdasarkan Suhu dan Lama Penyimpanan', Jurnal Kesehatan Andalas, 5(2), pp. 355-360.

Notoatmodjo, S. (2010) Metodologi Penelitian Kesehatan. Pertama. Jakarta: PT Rineka Cipta.

Nurkholidah, Ilza, M. and Jose, C. (2012) 'Analisis Kandungan Boraks pada Jajanan Bakso Tusuk di Sekolah Dasar di Kecamatan Bangkinang Kabupaten Kampar', Jurnal Ilmu Lingkungan, pp. 134-145.

Padmaningrum, R. T. and Marwati, S. (2013) 'Tester Kit untuk Uji Boraks dalam Makanan', Jurnal Penelitian Saintek, 18(1), pp. 24-33. 